\title{
An Effective New Treatment of Fluoride-Containing Sludge Resulting from the Manufacture of Photovoltaic Cells
}

\author{
Svetlana Zueva ${ }^{1,2, *}$, Francesco Ferella ${ }^{1}\left(\mathbb{D}\right.$, Valentina Corradini ${ }^{1}$, Elena V. Baturina ${ }^{2}$, Nicolò M. Ippolito ${ }^{1}$ \\ and Francesco Vegliò ${ }^{1}(\mathbb{D}$ \\ 1 Department of Industrial and Information Engineering and Economics, University of L'Aquila, \\ 67100 L'Aquila, Italy; francesco.ferella@univaq.it (F.F.); valentina.corradini@univaq.it (V.C.); \\ nicolomaria.ippolito@univaq.it (N.M.I.); francesco.veglio@univaq.it (F.V.) \\ 2 Department of Chemical Engineering, Voronezh State University of Engineering, 394036 Voronezh, Russia; \\ baturina1717@mail.ru \\ * Correspondence: svetlana.zueva@univaq.it; Tel.: +39-0862-434238
}

Citation: Zueva, S.; Ferella, F.; Corradini, V.; Baturina, E.V.; Ippolito, N.M.; Vegliò, F. An Effective New Treatment of Fluoride-Containing Sludge Resulting from the Manufacture of Photovoltaic Cells. Processes 2021, 9, 1745. https:// doi.org/10.3390/pr9101745

Academic Editor: Alessio Dessì

Received: 13 July 2021

Accepted: 27 September 2021

Published: 29 September 2021

Publisher's Note: MDPI stays neutral with regard to jurisdictional claims in published maps and institutional affiliations.

Copyright: (c) 2021 by the authors. Licensee MDPI, Basel, Switzerland. This article is an open access article distributed under the terms and conditions of the Creative Commons Attribution (CC BY) license (https:// creativecommons.org/licenses/by/ $4.0 /)$.

\begin{abstract}
The circular economy and maximization of environmental sustainability are increasingly becoming the vision and mission of companies competing in present-day global markets. In particular, in the energy sector, the transition from fossil fuels to renewable sources of energy has become the widespread mantra. One typical example is the deployment of devices which produce clean energy, such as solar photovoltaic panels and solar thermal panels, wind generators, tidal stream generators, wave power generators, etc. These are undoubtedly generating clean energy, but their manufacture creates hazardous by-products, the disposal of which results in increased environmental pollution. Chemical Vapor Deposition (CVD) is widely used in manufacturing of solar photovoltaic cells. In these processes, typically, crystalline silicon is precipitated from chlorosilanes, iodides, bromides and fluorides. Polluting by-products include deposition of a silicon film, formation of $\mathrm{SiO}_{2}$ powder and formation of toxic vapors of $\mathrm{HF}, \mathrm{SiH}_{4}$ and $\mathrm{PH}_{3}$. Usually, these gaseous products are eliminated in a central scrubber, whose unwanted by-product consists in large quantities of hazardous fluorinecontaining sludge. This article concerns an effective and inexpensive detoxification of fluorinated sludge, developed by the authors during research into the sludge collected from the scrubber of a PV cell manufacturing plant located in southern Italy.
\end{abstract}

Keywords: fluoride-containing sludge; precipitation; non-hazardous waste

\section{Introduction}

Annual new solar PV system installations increased from 29.5 GW in 2012 to 107 GW world-wide in 2018. The global photovoltaic (PV) energy capacity was nearly $520 \mathrm{GW}$ at the end of 2018 as installed power [1]. Thus, several hundred manufacturing plants have been setup worldwide, especially in Asia, to meet the growing demand.

China occupies a leading position with an installation rate of $175 \mathrm{GW}$ at the end of 2018 (34\% of the solar PV electric power capacity installed worldwide), thanks to the Chinese authorities' ambitions for the development of the internal PV market.

Solar energy has significant advantages over traditional energy sources. First, it is an extremely pure form of energy and, second, its use on a large scale does not interfere with the Earth's energy balance. It is estimated that without harm to the biosphere, it is possible to withdraw approximately $3 \%$ of the total solar irradiation of the planet.

However, environmental problems in the production of solar cells are similar to problems typical of the chemical and metallurgical industries. A variety of hazardous substances, including hydrochloric acid, sulfuric acid, nitric acid, hydrogen fluoride, and acetone are used in the solar cell production process.

The major raw material for the manufacture of silicon solar cells is trichlorosilane (a toxic silicon compound), which is subjected to distillation and is then reduced with hydro- 
gen to obtain ultrapure crystalline silicon. Chemical vapor deposition (CVD) processes are widely used in solar cell manufacturing and include deposition of crystalline silicon from chlorosilanes, iodides, bromides, and fluorides [2].

Solar cells based on amorphous silicon (a-Si:H) can be fabricated from extremely abundant raw materials and involve almost no ecological risk during manufacturing, operation, and disposal. However, some hazardous gas $\left(\mathrm{SiH}_{4}, \mathrm{Si}_{2} \mathrm{H}_{6}, \mathrm{HF}, \mathrm{PH}_{3}\right.$ and $\left.\mathrm{SiF}_{4}\right)$ mixtures are used to deposit a-Si:H. As a result, large quantities of unwanted by-products are generated, which usually go to the central scrubber of the plant. Their subsequent processing results in the formation of large quantities of hazardous fluoride-containing sludge, which is often discarded without further treatment. Its recycling is an important challenge for the photovoltaic industry [3,4]. If not properly treated or managed, it causes health and environmental problems. Instead, recycled, it can be recovered and transformed into artificial fluorite $\left(\mathrm{CaF}_{2}\right)$ or sodium fluorosilicate $\left(\mathrm{NaSiF}_{6}\right)$, which have economic and environmental benefits. Moreover, both materials can be used as substitutes for cement in construction.

Coagulation and lime precipitation are well-established techniques for fluoride removal. It has been previously demonstrated [5] that the removal of fluorides is maximized at $\mathrm{pH} 6-7$ and that aluminum is a more effective additive than iron. In particular, aluminum and iron sulfates were added in different amounts with an initial fluoride concentration of $50 \mathrm{mg} / \mathrm{L}$. The maximum fluoride removal was observed at $\mathrm{pH}$ 6-7 with an $\mathrm{Al}^{3+}$ concentration of $20 \mathrm{mmol} / \mathrm{L}$.

In [6], aluminum sulfate (alum) and poly-aluminium chloride (PACl) were used as coagulants to remove fluoride, after which the sludge was used as a partial replacement for fine aggregates in the production of mortar.

Hu et al. [7] coupled electrocoagulation with flotation for the treatment of semiconductor production wastewater. The fluoride ions were partially removed by precipitation with calcium in the electrolytic cell, where sodium dodecyl sulphate was added to enhance flotation. These treatments were effective for reducing fluorides and suspended solids in the wastewater. Jiang and Zhou studied the effect of aluminum on the treatment of fluorinecontaining synthetic wastewater by crystallization [8]. Wang et al. [9] demonstrated the effectiveness of calcium-containing precipitant calcite together with added precipitant fluorite to purify F-containing wastewater.

Instead of chemical precipitation, which produces large amounts of sludge, a fluidized bed reactor (FBR) can be applied to the treatment of wastewater containing fluorine [10]. This process represents a good alternative, in order to reduce solid waste and reuse calcium fluoride. Aldaco et al. [11] developed an original fluidization process to recover $\mathrm{CaF}_{2}$ from a synthetic fluoride solution. Granular calcite and silica were used as seed materials so that calcium fluoride could be recovered by crystallization in the fluidized bed reactor. The inlet concentration of fluoride was $250 \mathrm{mg} / \mathrm{L}$ and the final fluoride conversion was $92 \%$, with a $\mathrm{CaF}_{2}$ content in the solid material of $>97 \mathrm{wt} \%$.

Shin et al. [12] precipitated more than $99 \mathrm{wt} \% \mathrm{HF}$ and silicon during pretreatment of the solution and recovered $\mathrm{Na}_{2} \mathrm{SiF}_{6}$ with $98.2 \%$ commercial grade. The remaining solution contained $279 \mathrm{~g} / \mathrm{L}$ acetic acid, $513 \mathrm{~g} / \mathrm{L}$ nitric acid and some HF, and silicon was subjected to solvent extraction with 2-ethylhexyl alcohol. Acetic acid was stripped from the organic phase using deionized water, achieving $96.3 \%$ acetic acid recovery.

An integrated process including diffusion dialysis, anion exchange, and vacuum distillation was also developed to recover phosphoric acid from the mixed waste etching solutions containing $\mathrm{CH}_{3} \mathrm{COOH}, \mathrm{HNO}_{3}$, and $\mathrm{H}_{3} \mathrm{PO}_{4}$ with $\mathrm{Al}$ and Mo as metal impurities [13]. $\mathrm{Li}$ et al. demonstrated the effectiveness of the phosphoric-sulfonic acid bifunctional group chelating resin to remove fluoride from the aqueous phase [14].

Quercia et al. [15] studied the possibility of $\mathrm{SiO}_{2}-\mathrm{CaCO}_{3}$ sludge recycling. The compressive strength and pozzolanic activity of standard cement pastes and mortars with $7 \mathrm{wt} \%$ cement replacement were determined. The flexural and compressive strengths were similar to those of the fresh reference mortar. Nevertheless, minor replacement influenced the type 
and amount of hydrated phase, volume, porosity, and durability of the modified mortars, which requires further investigation.

Recycling of sludge composed of $\mathrm{SiO}_{2}-\mathrm{CaF}_{2}$ nanoparticles and recovered from treatment of wastewater of the semiconductor industry was investigated by Lee and Liu [16]. Dried and pulverized sludge was used to replace 5 to $20 \mathrm{wt} \%$ of the Portland cement in mortar. The compressive strength of the modified mortar was greater than that of the mortar composed of fresh cement after curing for 3 days. Moreover, the toxicity characteristic leaching procedure (TCLP) demonstrated that no heavy metals were released from the modified mortars. In another study, similar results were achieved using a different sludge produced from polishing operations of the integrated-circuit industry. This sludge, which is composed of hazardous compounds such as $\mathrm{SiO}_{2}, \mathrm{Al}_{2} \mathrm{O}_{3}, \mathrm{CaF}_{2}$, and unknown organics, was used to replace $10 \mathrm{wt} \%$ of the cement powder for concrete manufacturing. The compressive strength was comparable to that of ordinary Portland cement, whereas no metal release was detected by the TCLP test [15]. In another study, Lee [17] investigated the addition of PV sludge/fly-ash slag mixture for the production of cement mortar. The optimal mixture, as determined by the Taguchi method, was $20.9 \mathrm{wt} \%$ cement powder, $4.3 \%$ fly-ash slag, $3.4 \%$ PV sludge, and $71.4 \%$ sand. The optimal modified cement mortar showed increased compressive strength from the fourth day of curing onwards, reaching a maximum value of $132 \%$ after seven days with respect to the compressive strength of mortar composed of fresh Portland cement.

Bao et al. [18] attempted to recover silicon from PV waste sludge to manufacture next-generation lithium-ion batteries. The spray-drying method was used to recover silicon particles from the sludge, providing a high-grade and cost-effective silicon resource. Silicon carbide $(\mathrm{SiC})$ is a reusable material in the slurry generated during wafer slicing. The slurry underwent filtration to remove organic liquids, was washed with ethanol, and underwent sequential treatments with $\mathrm{NaOH}$ and a mixture of $\mathrm{HCl}$ and $\mathrm{HF}$ to remove residual metals. The remaining $\mathrm{SiC}$, once washed and dried, was used as a photocatalyst to produce hydrogen [19].

The recycling of PV industry sludge is important to prevent potential hazards to the environment. Thus, it is obvious that processing into a class of non-hazardous waste and further recycling will have a positive impact on the development of the industry. The aim of this study was to determine an efficient and low-cost detoxification of fluoride-containing sludge resulting from CVD processes collected after scrubber treatment in a PV plant located in Southern Italy.

\section{Materials and Methods}

\subsection{Chemicals and Solutions}

Silicon sludge waste was supplied by a PV thin-film solar cell plant located in Southern Italy. Fluoride-containing sludge resulting from CVD processes was collected after filter cartridge treatment.

Analytical grade reagents $\left(\mathrm{Ca}(\mathrm{OH})_{2}\right.$ and $\left.\mathrm{Al}_{2}\left(\mathrm{SO}_{4}\right)_{3}\right)$ were used for the experimental runs. For all fluoride-containing solutions, only polypropylene (PP) vessels were used for sample preparation and storage.

\subsection{Analytical Methods}

The XRF spectrophotometer (Spectro XEPOS 2000) and atomic spectroscope Agilent Synchronous Vertical Dual View (5100 ICP-OES, Agilent, Santa Clara, CA, USA) were used for chemical analyses of the wastewater and related precipitates.

Infrared spectroscopy (FTIR, Impact 410 Nicolet spectrophotometer, Thermo Fisher Scientific, Waltham, WA, USA) was used to characterize the obtained precipitate.

For fluoride content determination, the SPADNS method was used. Determining fluoride is based on the reaction of fluoride with a red solution of zirconium dye to form a colourless complex, so the colour intensity of the solution corresponds to its concentration, with a 95\% confidence interval. The Dr. Lange F-Standard Cuvette Tests (0.1-2.5 mg/L F) 
were used and then fluoride were measured with a Dr. Lange Spectrophotometer 145 (XION 500, Hach Company, Loveland, CO, USA) at the $580 \mathrm{~nm}$ wavelength.

\subsection{Experimental Methods}

During the precipitation step, $10 \mathrm{wt} \%$ solutions of $\mathrm{Ca}(\mathrm{OH})_{2}$ were gradually added to the studied sludge under constant stirring until reaching the desired $\mathrm{pH}$. The mixture was further stirred for $2 \mathrm{~h}$ to ensure that precipitation equilibrium was reached. Precipitation tests were performed at $\mathrm{pH} 1.5-8.9$ at room temperature $\left(25 \pm 2{ }^{\circ} \mathrm{C}\right)$. The final $\mathrm{pH}$ was then measured and the precipitate separated from the slurry via vacuum filtration, washed with demineralized water, and subsequently dried at $105^{\circ} \mathrm{C}$ overnight. Precipitation tests with $\mathrm{Al}_{2}\left(\mathrm{SO}_{4}\right)_{3}$ were performed simultaneously with lime.

The settleability of the sludge obtained from the wastewater treatment was measured using the 30 min settling test (SV30 test). First, $100 \mathrm{~mL}$ of well-mixed sludge and treated water was transferred to a measuring cylinder and equilibrated for $30 \mathrm{~min}$. The volume of the precipitated sludge was subsequently measured.

Moreover, to determine the hazard level of the solid precipitates, the samples were subjected to TCLP according to UNI EN 12457-2.

\section{Results and Discussion}

\subsection{Characterization of the Sludge}

To determine the chemical composition of the sludge (water content $84.6 \%$ ), the samples were centrifuged to achieve liquid/solid phase separation.

Based on X-ray fluorescence (XRF) measurements, the main components of the crystal phase were found $\mathrm{SiO}_{2}$ (Table 1).

Table 1. Semiquantitative analysis of the crystal phase of the sludge.

\begin{tabular}{ccccccc}
\hline & \multicolumn{7}{c}{$\%$ w/w } \\
\cline { 2 - 7 } & $\mathrm{SiO}_{\mathbf{2}}$ & $\mathrm{SO}_{3}$ & $\mathrm{Al}_{2} \mathbf{O}_{3}$ & $\mathbf{P}_{\mathbf{2}} \mathrm{O}_{5}$ & $\mathrm{Fe}_{\mathbf{2}} \mathrm{O}_{3}$ & $\mathbf{K}_{\mathbf{2}} \mathbf{O}$ \\
\hline Crystal Phase & 99.65 & 0.22 & 0.03 & 0.026 & 0.018 & 0.011 \\
\hline
\end{tabular}

The crystal phase of the sludge obtained from wastewater treatment was analyzed by infrared (IR) spectroscopy. The obtained IR spectra of the crystal phase of the studied sludge before (green line) and after drying (red line) were characteristic of $\mathrm{SiO}_{2} \mathrm{nH}_{2} \mathrm{O}$ (blue line; Figure 1).

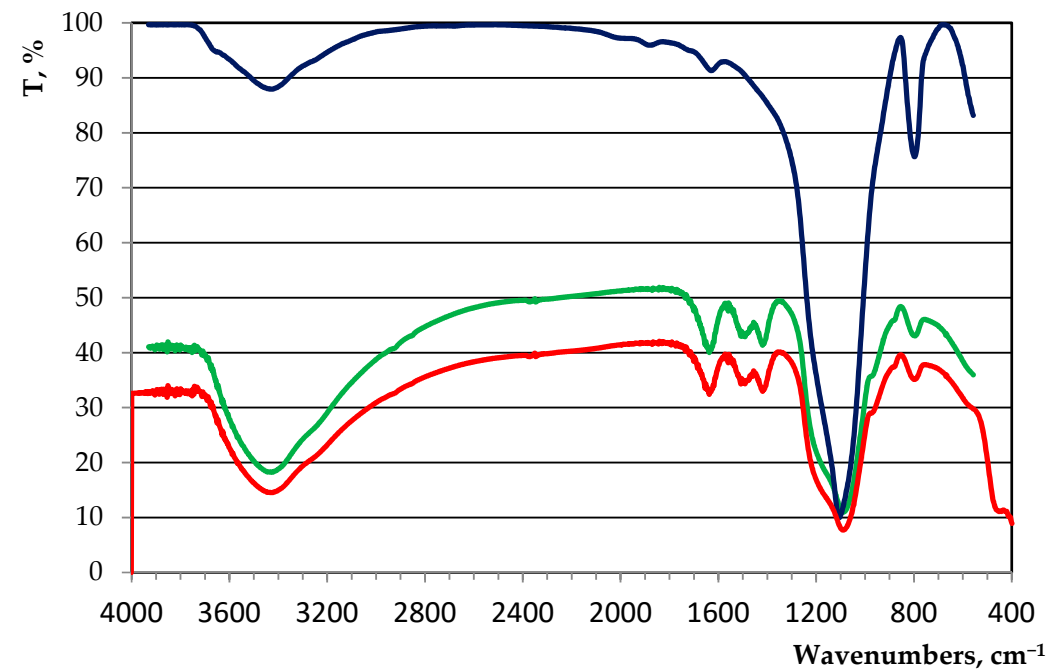

Figure 1. IR spectrum of the crystal phase of the studied sludge. 
The elution of fluoride ions from the sludge was studied. The crystal phase after filtration was washed with distillated water in a 2:1 ratio. Concentration of elements in the liquid phase of the sludge and washing water are given in Table 2.

Table 2. Characterization of the Liquid Phase of the Sludge.

\begin{tabular}{cccccccccc}
\hline & $\mathbf{p H}$ & $\mathbf{9}$ & $\mathbf{9}$ & $\mathbf{~ m g / L}$ \\
\cline { 3 - 10 } & & $\mathbf{S i}$ & $\mathbf{F}$ & $\mathbf{K}$ & $\mathbf{C a}$ & $\mathbf{N a}$ & $\mathbf{F e}$ & $\mathbf{P}$ & $\mathbf{A l}$ \\
\hline Liquid phase & 1.3 & 1612 & 6000 & 4.9 & 14.2 & 10.8 & 6.1 & 2.8 & 0.34 \\
Washing water & 1.5 & 1038 & 2260 & 1.5 & 9.0 & 2.9 & 2.0 & 0.6 & 0.14 \\
\hline
\end{tabular}

The release of pollutants from the sludge may endanger landfill management. Based on the results of the analysis of the studied sludge, it can be classified as hazardous waste (CER code: $100118^{*}$ ) due to the high concentration of fluorine.

\subsection{Efficiency of Fluoride Removal and Sludge Generation by Different Reagents}

The core objective of these experimental studies was to achieve the production of non-hazardous waste. For this reason, various regents and procedures were applied.

In the first set of experiments, the efficiency of fluoride removal obtained after precipitation with Ca hydroxides was studied from $\mathrm{pH} 1.5$ to 8.9. The composition of the liquid phase of the sludge after treatment at different $\mathrm{pH}$ values and centrifugation is presented in Table 3.

Table 3. Quantitative analysis of the liquid phase of sludge after treatment with lime at different $\mathrm{pH}$ values.

\begin{tabular}{|c|c|c|c|c|c|c|c|}
\hline \multirow{2}{*}{$\mathrm{pH}$} & \multirow{2}{*}{$\mathrm{Ca}(\mathrm{OH})_{2}, \mathrm{~g} / \mathrm{L}$} & \multicolumn{6}{|c|}{$\mathrm{mg} / \mathrm{L}$} \\
\hline & & Si & F & $\mathbf{K}$ & $\mathrm{Ca}$ & $\mathrm{Na}$ & Mg \\
\hline 1.5 & - & 1612.2 & 6000 & 4.9 & 14.2 & 10.8 & 4.5 \\
\hline 4.2 & 5.2 & 119.3 & 185 & 6.1 & 13.2 & 0.2 & 1.1 \\
\hline 6.2 & 10.5 & 82.7 & 68 & 4.7 & 24.5 & 0.4 & 1.5 \\
\hline 8.9 & 12.2 & 76.8 & 37 & 4.8 & 31.9 & 3.4 & 1.89 \\
\hline
\end{tabular}

The settleability of the sludge generated by lime treatment was analyzed using the SV30 method. The sludge generated after treatment at $\mathrm{pH} 8.9$ was completely precipitated within $20 \mathrm{~min}$, whereas the sludge generated after treatment at $\mathrm{pH}$ values of 4.2 and 6.2 was not settled after $30 \mathrm{~min}$ (Figure 2).

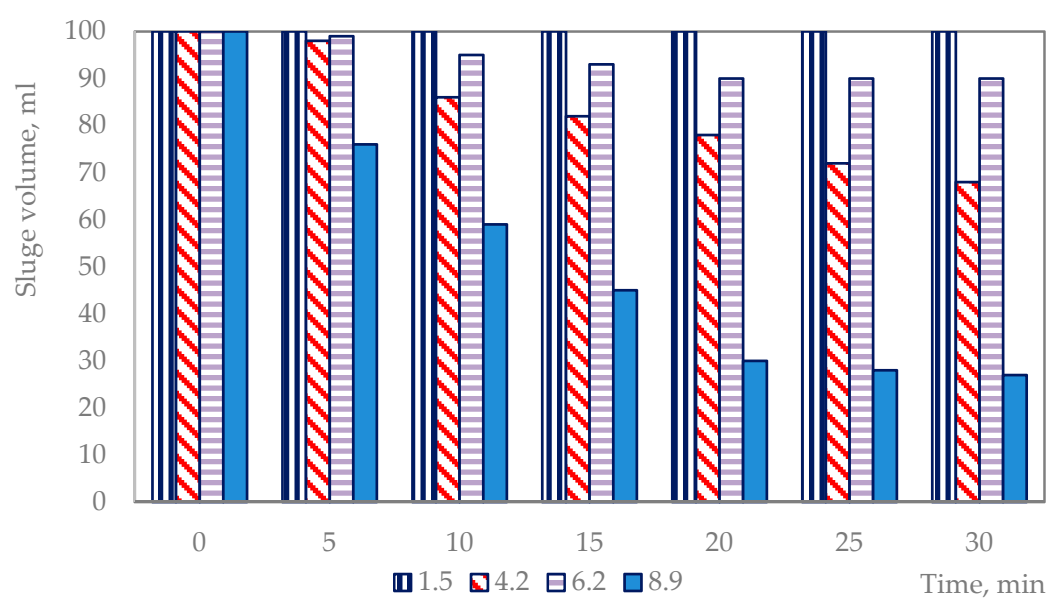

Figure 2. Settleability of the sludge generated before and after treatment with lime at different $\mathrm{pH}$ values. 
By adding calcium hydroxide and correspondingly increasing the $\mathrm{pH}$ from 1.5 to 6.2, polymerization of the sol of $\left[\mathrm{mH}_{4} \mathrm{SiO}_{4} \mathrm{nH}_{3} \mathrm{SiO}^{4-}(\mathrm{n}-\mathrm{x}) \mathrm{H}^{+}\right]^{\mathrm{x}-}$ to the gel $\mathrm{xCaO} \cdot \mathrm{ySiO} \mathrm{zH}_{2} \cdot \mathrm{zH}_{2} \mathrm{O}$ occurred. Here, the solvent molecules were enclosed in a flexible, but fairly stable threedimensional network formed by the added hydroxide particles.

Increasing $\mathrm{pH}$ values above 7 resulted in the formation of negatively charged $\mathrm{OH}^{-}$ groups on the surface of the particles. This led to enhanced adsorptive capacity of $\mathrm{Ca}^{2+}$, creating favorable conditions for the formation and deposition of calcium-silicate complexes. Here, increasing the $\mathrm{pH}$ to $8-9$ resulted in gel destabilization and improved filtration properties of the formed sludge.

The results of the experiments suggest that fluoride and phosphate removal by hydrated lime involves a combination of chemical adsorption on the surface of the lime particles, ion exchange of $\mathrm{F}^{-}$with $\mathrm{OH}^{-}$, and some direct precipitation.

From Table 4, it is clear that fluoride removal from the liquid phase was $99.4 \%$ at $\mathrm{pH} 8.9$, with final fluoride concentration in the solution of $37 \mathrm{mg} / \mathrm{L}$.

Table 4. Characterization of the liquid phase of sludge after treatment with lime.

\begin{tabular}{cccccccc}
\hline & & $\mathbf{7}$ & \multicolumn{7}{c}{$\mathbf{m g} / \mathbf{L}$} \\
\cline { 3 - 8 } & & $\mathbf{S i}$ & $\mathbf{F}$ & $\mathbf{K}$ & $\mathbf{C a}$ & $\mathbf{N a}$ & $\mathbf{P}$ \\
\hline Liquid phase & 8.0 & 12 & 37 & 0.2 & 21.0 & 8.2 & $<0.1$ \\
Washing water 1 & 7.8 & 8.3 & 27.8 & $<0.1$ & 7.5 & 1.5 & $<0.1$ \\
Washing water 2 & 7.1 & 4.3 & 16.4 & $<0.1$ & 3.2 & 0.5 & $<0.1$ \\
\hline
\end{tabular}

After the crystal phase separation, two washing steps were performed. The residual solutions, washing water 1 and 2, contained concentrations of $\mathrm{F}^{-}$of 27.8 and $16.4 \mathrm{mg} / \mathrm{L}$ (Table 4).

To reduce the residual fluoride content in the liquid phase, application of aluminium sulfate $\left(\mathrm{Al}_{2}\left(\mathrm{SO}_{4}\right)_{3} 18 \mathrm{H}_{2} \mathrm{O}\right)$ was investigated. As the original liquid phase of the sludge was characterized by high $\mathrm{pH}$ value, reagent was added at the beginning, before adding calcium hydroxide. In this case, the aluminium salt hydrolysis products $\left(\left[\mathrm{Al}_{8}(\mathrm{OH})_{20}\right]^{+4}\right)$ were the center of the formation of calcium phosphate and calcium fluoride during the addition of lime.

Alumina in the process of extracting fluoride ions acts as an anion exchange resin, whose surface was saturated with various adsorption centers [20,21]. On the other hand, along with the precipitation with lime, chemical interaction between the fluoride and aluminum ions with the formation of sorbed alumina fluoride complexes occurred as follows:

$$
\mathrm{Al}^{3+}+\mathrm{nF}^{-} \rightarrow\left(\mathrm{AlF}_{\mathrm{n}}\right)^{3-\mathrm{n}}
$$

The results of the experiments demonstrate the advantages of sludge defluorination by lime combined with aluminium sulfate. Residual concentration of fluoride decreased from 37 to $14.9 \mathrm{mg} / \mathrm{L}$ (Figure 3).

The resulting crystal phase showed good filtration characteristics. The precipitate generated after treatment with lime and $\mathrm{Al}_{2}\left(\mathrm{SO}_{4}\right)_{3}$ was completely precipitated within $10 \mathrm{~min}$, which is twice as fast as that observed when precipitating only with lime.

This research has proven that joint use of aluminum sulfate and lime was effective in the treatment of silicon sludge waste supplied by a PV thin-film solar cell plant. Results of the experiment identify the optimum dosage of reagents to obtain maximum fluoride removal and allow us to draw the following conclusions. 


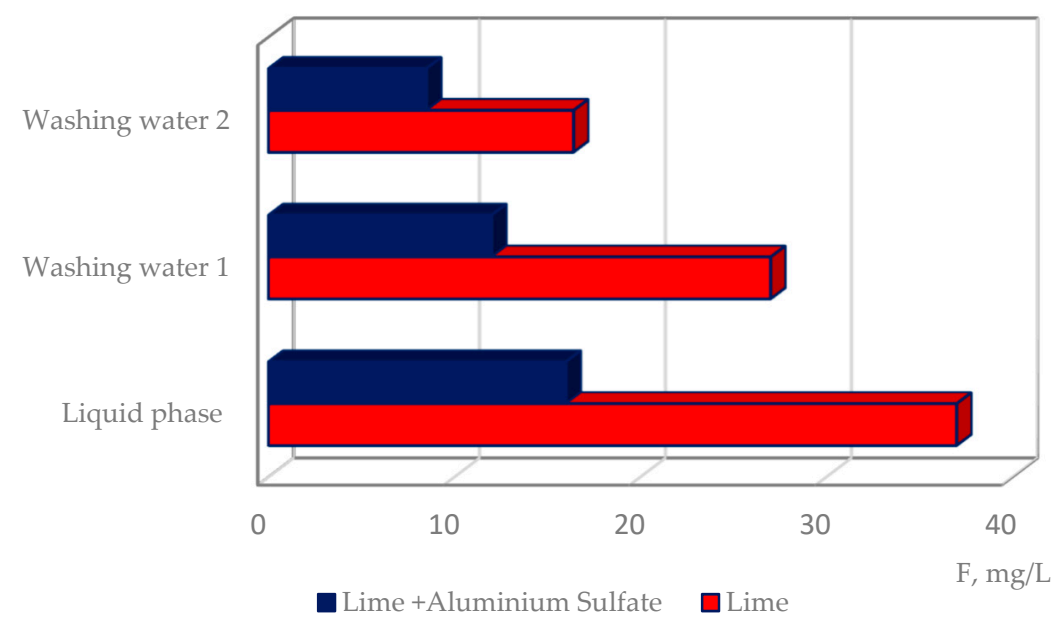

Figure 3. The effect of different reagents on the treatment efficiency of the studied sludge.

The process is more effective if staggered as follows:

1. Adding powder of aluminum sulfate and stirring for $15 \mathrm{~min}$. This time is required for hydrolysis of the reagent and formation of a positively charged complex $\left[\mathrm{Al}_{8}(\mathrm{OH})_{20}\right]^{+4}$ that can play the role of nucleating agent.

2. Adding $\mathrm{o} 10 \%$ solution of $\mathrm{Ca}(\mathrm{OH})_{2}$ up to $\mathrm{pH}=8-9$ at constant mixing for $1 \mathrm{~h} 45 \mathrm{~min}$.

3. Following precipitation.

Under these conditions, the effect of the removal of fluoride from the liquid phase was $99.9 \%$. Concentration of fluorides in the liquid phase after treatment was below the discharge standard of fluoride in industrial wastewater $(15 \mathrm{mg} / \mathrm{L})$ which made it possible to reintroduce it into the scrubbing cycle.

On the other hand, according to the results of the TCLP test (UNI EN 12457-2) of the crystal phase, after lime and aluminium sulfate treatment, only $8.5 \mathrm{mg} / \mathrm{L}$ of fluorides remained in the solution. As a result, the lime- $\mathrm{Al}_{2}\left(\mathrm{SO}_{4}\right)_{3}$ treatment allowed the transformation of hazardous (CER 100118*) to non-hazardous (CER 100119) waste.

\section{Conclusions}

The results of the experiments demonstrate that sludge defluoridation via treatment with lime was $99.4 \%$, with a residual fluorine content in the liquid phase of $37 \mathrm{mg} / \mathrm{L}$.

The introduction of aluminium sulfate during the last stage of purification reduced the residual fluoride concentration in the liquid phase of the sludge to $14.9 \mathrm{mg} / \mathrm{L}$ and reduced the sedimentation rate of the crystal phase by half.

The obtained IR spectra and results of the XRF analysis of the crystal phase of the sludge were characteristic of $\mathrm{SiO}_{2} \mathrm{nH}_{2} \mathrm{O}$.

According to the TCLP test of the crystal phase, the lime- $\mathrm{Al}_{2}\left(\mathrm{SO}_{4}\right)_{3}$ precipitation of fluorides allowed for the transformation of hazardous waste (CER 100118*) to nonhazardous (CER 100119) waste according to the European Waste Catalogue and Hazardous Waste List.

Author Contributions: Conceptualization, S.Z. and F.V.; methodology, S.Z.; software, N.M.I.; validation, F.V, F.F. and V.C.; formal analysis, E.V.B.; investigation, S.Z.; resources, V.C.; data curation, N.M.I.; writing—original draft preparation, S.Z.; writing—review and editing, S.Z.; visualization, E.V.B.; supervision, F.V.; project administration, F.V.; funding acquisition, F.F. All authors have read and agreed to the published version of the manuscript.

Funding: This research received no external funding.

Institutional Review Board Statement: Not applicable.

Informed Consent Statement: Not applicable. 
Data Availability Statement: Not applicable.

Acknowledgments: Authors are very grateful to Fabiola Ferrante and Marcello Centofanti for their helpful collaboration during the XRF, IRS, and AAS analyses.

Conflicts of Interest: The authors declare no conflict of interest.

\section{References}

1. Jäger-Waldau, A. PV Status Report 2019, EUR 29938EN; Publications Office of the European Union: Luxembourg, 2019; ISBN 978-92-76-12608-9. [CrossRef]

2. Adhikari, S.; Kayastha, M.S.; Ghimire, D.C.; Aryal, H.R.; Adhikary, S.; Takeuchi, T.; Murakami, K.; Kawashimo, Y.; Uchida, H.; Wakita, K.; et al. Improved Photovoltaic Properties of Heterojunction Carbon Based Solar Cell. J. Surf. Eng. Mater. Adv. Technol. 2013, 3, 178-183. [CrossRef]

3. Li, J.; Lin, Y.; Shi, J.; Ban, B.; Sun, J.; Ma, Y.; Wang, F.; Lv, W.; Chen, J. Recovery of high purity Si from kerf-loss Si slurry waste by flotation method using PEA collector. Waste Manag. 2020, 115, 1-7. [CrossRef] [PubMed]

4. Sergiienko, S.A.; Pogorelov, B.V.; Daniliuk, V.B. Silicon and silicon carbide powders recycling technology from wire-saw cutting waste in slicing process of silicon ingots. J Sep. Purif. Technol. 2014, 133, 16-21. [CrossRef]

5. Aoudj, S.; Drouiche, N.; Hecini, M.; Ouslimane, T.; Palaouane, B. Coagulation as a Post-Treatment Method for the Defluoridation of Photovoltaic Cell Manufacturing Wastewater. Procedia Eng. 2012, 33, 111-120. [CrossRef]

6. Dubey, S.; Agarwal, M.; Gupta, A.B. Use of waste sludge generated from water defluoridation plant as partial substitute for fine aggregates in mortars: Microstructural characterization and compressive strength. J. Mater. Cycles Waste Manag. 2019, 21, 1526-1540. [CrossRef]

7. Hu, A.H.; Hung, C.H.; Hong, C.S.; Huang, L.C. Carbon Footprint Assessment of Recycling Fluorspar from Waste Calcium Fluoride $\left(\mathrm{CaF}_{2}\right)$ Sludge. Waste Manag. Resour. Effic. 2019, 685-693. [CrossRef]

8. Jiang, K.; Zhou, K. Removal and recovery of fluoride from wastewater by crystallization: Effect of aluminum. Sep. Sci. Technol. 2018, 54, 1241-1246. [CrossRef]

9. Wang, L.; Zhang, Y.; Sun, N.; Sun, W.; Hu, Y.; Tang, H. Precipitation Methods Using Calcium-Containing Ores for Fluoride Removal in Wastewater. Minerals 2019, 9, 511. [CrossRef]

10. Zeng, G.; Ling, B.; Li, Z.; Luo, S.; Sui, X.; Guan, Q. Fluorine removal and calcium fluoride recovery from rare-earth smelting wastewater using fluidized bed crystallization process. J. Hazard. Mater. 2019, 373, 313-320. [CrossRef] [PubMed]

11. Aldaco, R.; Garea, A.; Irabien, A. Calcium fluoride recovery from fluoride wastewater in a fluidized bed reactor. Water Res. 2007, 41, 810-818. [CrossRef] [PubMed]

12. Shin, C.H.; Kim, J.Y.; Kim, J.Y.; Kim, H.S.; Lee, H.S.; Mohapatra, D.; Ahn, J.W.; Ahn, J.G.; Bae, W. A solvent extraction approach to recover acetic acid from mixed waste acids produced during semiconductor wafer process. J. Hazard. Mater. 2009, 162, 1278-1284. [CrossRef] [PubMed]

13. Kim, J.-Y.; Shin, C.-H.; Choi, H.; Bae, W. Recovery of phosphoric acid from mixed waste acids of semiconductor industry by diffusion dialysis and vacuum distillation. Sep. Purif. Technol. 2012, 90, 64-68. [CrossRef]

14. Li, R.; Tian, X.; Ashraf, I.; Chen, B. Fluoride Removal Usinga Chelating Resin Containing Phosphonic-Sulfonic Acid Bifunctional Group. J. Chromatogr. A. 2019, 1613, 460697. [CrossRef] [PubMed]

15. Quercia, G.; Van der Putten, J.J.G.; Hüsken, G.; Brouwers, H.J.H. Photovoltaic's silica-rich waste sludge as supplementary cementitious material (SCM). Cem. Concr. Res. 2013, 54, 161-179. [CrossRef]

16. Lee, T.C.; Lin, K.L.; Su, X.W.; Lin, K.K. Recycling CMP sludge as a resource in concrete. Constr. Build Mater. 2012, 30, $243-251$. [CrossRef]

17. Lee, T.C. Recycling of municipal incinerator fly-ash slag and semiconductor waste sludge as admixtures in cement mortar. Constr. Build Mater. 2009, 23, 3305-3311. [CrossRef]

18. Bao, Q.; Huang, Y.H.; Lan, C.K.; Chen, B.H.; Duh, J.G. Scalable upcycling silicon from waste slicing sludge for high-performance lithium-ion battery anodes. Electrochim. Acta 2015, 173, 82-90. [CrossRef]

19. Zhang, Y.; Hu, Y.; Zeng, H.; Zhong, L.; Liu, K.; Cao, H.; Li, W.; Yan, H. Silicon carbide recovered from photovoltaic industry waste as photocatalysts for hydrogen production. J. Hazard. Mater. 2017, 329, 22-29. [CrossRef] [PubMed]

20. Raichur, A.M.; Basu, M.J. Adsorption of fluoride onto mixed rare earth oxides. Sep. Purif. Technol. 2001, 24, 121-127. [CrossRef]

21. Chorai, S.; Pant, K.K. Investigations on the column performance of fluoride adsorption by activated alumina in a fixed-bed. Chem. Eng. J. 2004, 98, 165-173. 